\title{
THE PROFIT SHARING IMPLEMENTATION FOR FINANCING IN INDONESIAN SHARIA BANKING
}

\author{
Aidha Trisanty \\ Banking and Finance Department, Diploma III of Economics \\ Universitas Islam Indonesia, Yogyakarta, Indonesia \\ email: aidha.trisanty@uii.ac.id
}

\begin{abstract}
One of the characteristics of Islamic banking is using the concept of profit loss sharing. This characteristic distinguishes the operation of Islamic banking with conventional banking. In applying the concept of profit loss sharing, most of the activities of Islamic banking especially in the distribution of funds or financing are actually dominated by the profit - loss sharing agreement. However, financing in the Islamic banking today mostly is dominated by features that use nonprofit-sharing agreement such as murabahah. This paper examines about why the realization of financing of Islamic banking in Indonesia is still dominated by financing non-profit-sharing, and what solutions can be done in order to increase the financing based on profit loss sharing concept. This is consistent with the objectives stated in the blueprint for the development of Islamic banking in Indonesia, which clearly states that the vision will be achieved ten years. They are to establish Islamic banking system that is competitive, efficient, which meets the prudential principle, and to support the real sector through profit sharing financing and real transactions in the context of fairness, mutual help, and for betterment in order to achieve the mutual benefits for the society
\end{abstract}

Key words: Mudharabah, musyarakah, Islamic banking, profit sharing, sharia financing.

\section{Introduction}

Indonesian Islamic banking has been continuously developing in the last two decades. The Banking Act Number 10 Year 1998 has regulated in detail about the legal basis and type of business that can be operated by sharia banking. In addition, some policy and rules from Central Bank of Indonesia endorsed the efforts to improve the knowledge of the society about sharia banking and fatwa from Indonesian Ulama Council (Majelis Ulama Indonesia/M.U.I.) about bank interest has also pushed the growth of sharia banking.

In its operation, sharia bank as intermediary institution plays two main roles as fund collector from the society and fund distributor to the public. Different from conventional bank, sharia bank implements profit loss sharing mechanism. In the activity of fund collection, the principles of profit loss sharing mechanism is implemented in saving product and deposit that used mudharabah agreement (akad). Meanwhile, in the activity of financing distribution, the financing implements agreement (akad) of mudharabah and musyarakah.

Since it implements profit loss sharing concept, the activity in sharia bank especially fund distribution or financing is actually dominated by akad of profit sharing [8]. However, financing in Indonesian sharia bank at this time is dominated by products that implements non-profit sharing such as murabahah. The statistics of Indonesian sharia banking indicated that in the last five year, the realization of financing with profit sharing principle is around $32 \%$ per year, which consists of $7 \%$ 
of financing with mudharabah and $25 \%$ for financing with musyarakah. The highest realization of financing in the akad murabahah is $58.4 \%$ [4]. In detail, the statistics can be seen in table 1 and 2 below.

Table 1. Composition of Funding in Sharia Public Bank and Sharia Business Unit (in Billion Rupiah)

\begin{tabular}{lrrrrr}
\hline \hline \multirow{2}{*}{ Akad } & \multicolumn{5}{c}{ Year } \\
\cline { 2 - 6 } & 2012 & 2013 & 2014 & 2015 & \multicolumn{1}{c}{2016} \\
\hline \hline Mudharabah & 12.023 & 13.625 & 14.354 & 14.820 & 15.292 \\
Musyarakah & 27.667 & 39.874 & 49.387 & 60.713 & 78.421 \\
Murabahah & 88.004 & 110.565 & 117.371 & 122.111 & 139.536 \\
Salam & 0 & 0 & 0 & 0 & 0 \\
Istishna & 376 & 582 & 633 & 770 & 878 \\
ljarah & 7.345 & 10.481 & 11.620 & 10.631 & 9.150 \\
Qardh & 12.090 & 8.995 & 5.965 & 3.951 & 4.731 \\
Others & 0 & 0 & 0 & 0 & 0 \\
Amount & 147.505 & 184.122 & 199.330 & 212.996 & 248.008 \\
& & & & & \\
\hline \hline
\end{tabular}

Source : Sharia Banking Statistic, 2017

Table 2. Composition of Funding in Sharia Public Bank and Sharia Business Unit (in percentage)

\begin{tabular}{lcccccc}
\hline \multirow{2}{*}{ Akaa } & \multicolumn{5}{c}{ Year } & Average \\
\cline { 2 - 6 } & 2012 & 2013 & 2014 & 2015 & 2016 & per Year \\
\hline \hline Mudharabah & 8,15 & 7,40 & 7,20 & 6,96 & 6,17 & 7,18 \\
Musyarakah & 18,76 & 21,66 & 24,78 & 28,50 & 31,62 & 25,06 \\
Murabahah & 59,66 & 60,05 & 58,88 & 57,33 & 56,26 & 58,44 \\
Salam & 0,00 & 0,00 & 0,00 & 0,00 & 0,00 & 0,00 \\
Istishna & 0,25 & 0,32 & 0,32 & 0,36 & 0,35 & 0,32 \\
ljarah & 4,98 & 5,69 & 5,83 & 4,99 & 3,69 & 5,04 \\
Qardh & 8,20 & 4,89 & 2,99 & 1,85 & 1,91 & 3,97 \\
Others & 0,00 & 0,00 & 0,00 & 0,00 & 0,00 & 0,00 \\
Total & 100 & 100 & 100 & 100 & 100 & 100 \\
\hline \hline
\end{tabular}

Source : Sharia Banking Statistic, 2017 (Processed Data)

The domination of akad murabahah in the composition of financing has become a big question in Indonesian sharia banking because actually akad mudharabah and musyarakah should be dominant as the manifestation of profit loss sharing principles. Besides, the blueprint of Indonesian sharia banking has clearly mentioned the vision and mission that will be achieved in the next ten years. It aims to realize competitive, efficient, and prudent sharia banking system and to support profit loss sharing and real transaction for creating justice, helping each other, and heading to goodness for the benefits of society [10]. To accomplish the vision, some solution is required to make profit loss sharing financing become the main financing distributed by sharia banking.

This paper aims to identify the barriers in the implementation of profit loss sharing principles especially in Indonesian sharia banking and to offer solution that will foster the domination of profit 
loss sharing as main option for financing product to support the attainment of vision as stated in the blueprint of Indonesian sharia banking development.

\subsection{Previous Research}

Previous research shows that there are challenges faced by the profit-and-loss sharing financing in Islamic banking institutions in Malaysia. The findings showed that there were four major obstacles to profit and loss sharing financing such as high risk of investment; difficulty in selecting appropriate partners; demand comes from low credit worthiness customers; and lack of capital security [18].

Other research is about the implication of using profit and loss sharing modes of finance in the banking system, with a particular reference to equity participation (partnership) method in Sudan. The results show the high preference of musharakah among banks" staff compared with other modes of finance. The results indicate that the lack of knowledgeable bankers in selecting, evaluating and managing profitable projects is a significant cause for the lack of profit and loss projects. The results show the high profitability and risk performance [19].

\section{Litterature Review}

\subsection{Overview about Sharia Bank}

Sharia bank is bank that operates its business activity based on the principles of sharia and refers to the fatwa of authoritative institution, in this case National Board of Sharia (Dewan Sharia Nasional/D.S.N.,) under M.U.I [2]. In its operation, sharia bank has differences with conventional bank, in which of them is the concept of profit and loss sharing for sharia bank, and interest for conventional bank [12]. By using sharia principles, the transaction in sharia bank is free from uncertainty, gambling, and interest [11].

\subsection{Principles of Profit Sharing in Funding}

The implementation of profit and loss sharing for financing in sharia bank is done through akad mudharabah and musyarakah. Mudharabah is cooperation between two parties or more in which the capital owner trust and allow the fund manager to manage the funding in a mutual agreement [12]. In akad mudharabah, the capital owner, in this case the bank provides $100 \%$ funding while the customer provides skills. The loss that might happen in the cooperation used akad mudharabah, which will be covered by the capital owner, unless if the loss is caused by the carelessness or dishonesty of fund manager. Meanwhile, musyarakah is cooperation where each party will contribute some funds. The profit and risk in akad musyarakah will be collective responsibility based on initial agreement [12].

Similar definition is stated that musyarakah is akad of cooperation based on collective agreement to share profit and loss in running a business [1]. The profit obtained will be shared based on previously agreed ratio while the loss will be the responsibility of each party based on each capital contribution. Whereas, in mudharabah financing, the profit will be distributed to each party based on previously agreed ratio and if loss happens, the fund owner (shahibul maal), in this case the bank will cover the loss.

Another explanation about mudharabah is formulated and stating that mudharabah is:

"Akad or agreement of cooperation between first party (malik, shahibul maal or sharia bank) that provides the whole capital and second party ('amil, mudharib, or customer) who acts as fund manager by sharing the business profit based on the agreement written in akad. While the loss will be fully covered by sharia bank unless the second party conduct intentional mistake, careless, or 
breaking the rules of agreement" [2].

Whereas, musyarakah is:

"Akad or agreement of cooperation between two or more parties for a certain business in which each party provides funding with the condition that there will be profit and loss sharing based on agreement and loss will be covered based on each portion of funding" [2].

\section{Research Methods}

This research is a qualitative research using interviews as a method of data collection comes with various literature study. Interview done to bankers who has position as the analys or financing staff who has been working for at least seven years in sharia banking.

This research is a descriptive-qualitative research by using questionnaire to the respondent in data collection. The questionnaires were given to senior analysts at the financing unit in all Sharia Commercial Banks and Syariah Business Unit in DI Yogyakarta (9 banks). From the results of the questionnaire distribution, there are seven questionnaires that can be processed in this research. The seven banks are; Bank BTN Syariah, Bank BNI Syariah, Bank Syariah Mandiri, Bank BRI Syariah, Bank Syariah Bukopin, Bank Syariah Mega Indonesia and Bank BPD DIY Syariah.

\section{Discussion}

Sharia bank acts as intermediary institution or mediator between fund owner and fund receiver. As the third party, the bank plays two different roles. When dealing with the owner of funds (current account, saving, deposits), bank will be the party to manage the funds. In this part, the bank is called as mudharib (fund manager) and the customer that owns the fund is called as shahibul maal while the customer who need and use the funds is called as mudharib. The customer who owns the funds and hands the money to the bank in form of currrent account, saving, and deposits, by using mudharabah principle will get monthly profit sharing. The profit sharing is determined based on the income of the bank from the financing distribution. The increase of bank income will result on increasing quantity of profit sharing. Consequently, when the bank income decreases, the profit shared to the fund owner will also decrease.

Current account, saving, and deposits, which are usually called as Third Party Funds (T.P.F.,) are closely related to the financing realization in sharia bank. The higher the number of funding collected by the bank from third party, the higher the realization of financing that could be done by sharia banking [6]. The increasing financing realization means increasing income of the bank and in the end the profit sharing for the customer will also increase. Considering T.P.F., as the main source of bank funding, then it is important for the bank to maintain and improve the growth of T.P.F., One of the efforts that can be done is by providing competitive profit sharing to the customer. To be able to provide it, sharia bank should manage and distribute the funds professionally and implement prudence principle at the same time.

The loss caused by distribution of funds or financing will influence the profit sharing that should be received by the customers who own the funds in current account, saving, and deposits that use akad mudharabah. The loss will cause problems to bank considering that Indonesian society recently are not ready to cover the risks of loss while making saving or deposits in sharia bank [8].

In its practice, sharia bank is faced with the possibility of customers who may transfer their funds. When conventional banks offer high interest rate, the customer may probably move the money from sharia bank. This tendency will increase the risk for sharia bank [7]. The main principle that 
should be developed by sharia bank in fund management is the bank should be able to provide profit sharing to the fund savers at least as big as or bigger than the interest rate of conventional bank [14]. It should also draw profit sharing from debtor lower than the interest rate in conventional bank. The connection between fund collection and financing is one of the reasons why the profit sharing funding is lower than non profit sharing funding, especially murabahah.

Table 3 shows the results of interview on the analysts of seven sharia banks about profit sharing financing in sharia banking.

Table 3. The Result of Interview on the Analysts

1. High turnover of human resources due to the development of the office continues to grow every time. The analyst with five years of working experience will generally be promoted to other work unit or positions, thus leaving new analyst who barely have experience in the financing process to directly deal with customers.

2. The analytical process of financing for profit sharing is more detailed and complicated compared to non profit sharing financing such as

BTN

Syariah

Bank

BNI

Syariah

Bank

Bank BRI

Syariah murabahah, so that analysts tend to lead customers to prioritize murabahah scheme for proposed financing if murabahah contract is applicable for the financing scheme.

3. Most customers prefer non profit-sharing financing than the profit sharing as it is simpler in terms and conditions. With this type of financing, the customer does not need to make an income estimate as in the profit sharing financing which requires an income estimate as one of the basis for assessing repayment capacity of the customer.

4. There is a certain tendency in which customers cover the actual operating income. In some cases, clients report financial bookkeeping that is not in accordance with the actual conditions.

1. In general, bank's business plan does set the house (griya/K.P.R.) product as one of the excellent products in Bank BNI Syariah which ensures constantly high focus and expansion.

2. Human Resources competencies are strictly incompatible with the need to analyze the profit sharing financing which requires more detailed competence. In fact, profit sharing financing is more risky because it highly depends on the flow of repayment. However, once the repayment cycle encounters any problems, the collectibility will go down to collectibility 3.

3. The Bank shall bear the risk of loss because it applies the profit sharing principle which incurs a potential decline in income.

4. It is possible that the customer's financial report is not appropriate with the actual condition providing that the customer disclose the truth. In consequence, the profit-sharing that the bank receives does not go with what it should be.

1. The benefit of Murabahah financing lies in the fact that it comes with low risk. This is mainly because the profit on murabahah financing has been determined in advance with fixed repayment. It is in contrast to profit sharing financing which comes with fluctuating repayment in accordance to the monthly income or profit of the customers. The decline of the customer's income will automatically decrease the bank income, which may affect the payment of profit sharing of current account customers, savings and time deposits using the mudharabah contract. 
2. Indonesia's sharia banking resources are currently inadequate, specifically in terms of quantity and quality of human resources, which impede the implementation of musharakah and mudharabah financing contracts that require supervision and close monitoring on the business unit of borrowing customers. Moreover, the various types of businesses/industries in the business world which do not always sound familiar to the management or human resources in Islamic banking makes the controlling task almost unmanageable.

3. Regulation is closely related to the collectibility of profit sharing financing. The disruption of the repayment on murabahah financing will gradually affect the collectibility of customers to the collectability (coll) of 2, 3, 4 up to be stuck in collectibility 5 . This is different from profit-sharing financing, where delayed repayment will result in the direct decrease of customer" $s$ collectibility to collectibility 3 . This will become more problematic if the financing has no guarantee because the profit of sharia bank will decrease because of the depreciation of Earning Asset Backup (P.P.A.P). Gradually the profit will decrease by $1 \%$ (in coll 1), 5\% (in coll 2), 15\% (in coll 3), 50\% (in coll 4) and 100\% (in coll 5).

4. One of Sharia banking difficulties is to determine the amount of profit sharing calculation/margin that requires truthfulness of both parties in running the investment/business of profit sharing, by always updating the income of the profit-sharing business to be monitored by the system.

1. The essential Islamic principle and requirements of murabahah financing are more easily fulfilled than other types of financing.

Bank Syariah Bukopin

Bank BPD Syariah

Bank Syariah Mandiri

Bank Syariah Mega Indonesia
2. It is easier for the customers to use murabahah contract than any other type of contract because they can easily make expense plan on repayment liabilities because price of goods and margin have been agreed at the beginning of contract until fully paid so that the repayment amount is kept constant until the end of the contract. This is in contrast to the profit sharing financing which requires detail explanation of customer" $s$ business income in a daily to monthly financial statements. These financial statements will become the basis to determine the amount of repayment incurred at the end of the month based on the ratio agreed upon at the contract.

1. Murabahah financing analysis is simpler because it does not require any periodical reporting as compared to syirkah contract.

2. Consumer demand for financing with murabahah contract is higher than any other type of contract, for example for the purchase of houses and vehicles.

1. Customers prefer murabahah contract because the use of murabahah contract is simpler than any other contracts. The Customer does not need to make an estimated income that will be used as the basis for the loan repayment.

2. Murabahah financing risk is lower than the profit sharing agreement. The decrease of customer" $s$ income in the profit-sharing financing will also decrease the bank income. This on the other hand will affect the revenue that will be distributed to customers who own giro, savings and deposits using the profit sharing contract.

1. Delinquent payments in murabahah financing will decrease the collectibility to col.2, in contrast to profit sharing financing in which the delinquency in repayment will immediately drop collectibility financing to 
coll.3 and cause a decrease in bank performance. This is one of the underpinning reasons for shariah banks to prefer using murabahah products than other products.

2. Murabahah financing is relatively more attractive to customers, as the process does not require them to estimate future income. Thus, the repayment of murabahah remains constant until the end of the financing period.

Source : Interview, 2017

Another factor that contributes to the slow development of profit and loss sharing is the complexity of financing analysis process in comparison to non profit sharing financing. Uncertainty about the result of monthly funded business demands sharia bank to conduct detail and in-depth analysis. Bank should make analysis to reduce the risks that might emerge especially when the income of the bank decreases. Sharia bank is also demanded to be able to distribute the financing prudently to the customers who needs the financing according to the banking regulation. Some aspects that need to be observed when conducting comprehensive analysis are characters, capacity of the customers, capital, business sustainability, and the guarantee.

In addition, when conducting analysis process, banks should also carefully examine the estimation of income made by the customer in the beginning of financing proposal making for the business that will be financed by the bank. This projection becomes crucial considering the regulation related to financing health level and performance of the customer for profit and loss sharing financing, which is determined by punctuality of repayment based on the estimation made in the initial process of financing. The customers can be categorized as smooth payment if they can pay back monthly based on the estimation that has been made. This will certainly become contradictory regarding to the uncertainty aspect in financing cooperation with profit and loss sharing principle. Consequently, the monthly income may fluctuate and even the customer may suffer from loss, which will not meet the previously made estimation.

The regulation is made not without some reasons. This rule is part of the attempts to prevent moral hazard such as side streaming or the usage of financing for customers who are not properly stated in the akad contract, carelessness of customer, and profit concealment caused by customer" $s$ dishonesty [16]. Moral hazard becomes one of the reasons why the bank prefers to have non profit sharing financing [13]. Customer" s recklessness may potentially result on loss in the business and damage the business of sharia bank especially if the profit sharing financing used the akad of mudharabah (capital inclusion) in which the bank will cover the loss.

Another factor that makes profit and loss sharing financing is less preferable is agency contractual in mudharabah financing. Agency contractual occurs when clash of needs between mudharib and shahibul maal happens. Mudharib tends to ignore the contractual relation and does not act based on the interest of shahibul maal or the agreement made initially. In mudharabah financing, the customer (mudharib) may possibly conceal some information for his or her personal interest. The information concealment will result on asymmetric information that might cause loss for the bank. This is in accordance with the research which stated that one of the barriers in the financing contract of sharia bank is asymmetric information in the form of adverse selection and moral hazard [17].

In the end, sharia bank should be extra prudent in conducting analysis process so that the bank is required to have competent human resources. Experiences from some Islamic countries proved that the success of profit sharing financing (mudharabah and musyarakah) is highly determined by 
banking parties who really understand the business that will be funded. Bank that is successful in distributing its profit and loss sharing based financing is bank that initially started its business as sharia business in which the bankers have considerable experience [15].

The average of Indonesian sharia banking growth in the last five year around 26 percent [4] has consequently increased the number of human resources working in the sector. The growth of employee number is dominated by new player who are commonly new to the business and has limited experience in conducting analysis for profit sharing financing. This becomes another cause of why the bank prefers to have non profit sharing financing. In murabahah financing, the analysis is designed to ensure the security and easiness because the margin has been decided in the beginning so that the bank will earn profit equal to profit of other bank or competitors that is based on interest rate [14].

To reduce the risks discussed above and to increase the realization of profit sharing-based financing, sharia bank may implement some particular limitation while distributing funds to customer (mudharib) [12]. It aims to „push" mudharib to systematically behave to maximize profits for both parties (mudharib and the bank as shahibul maal). Some of the regulations are the determination of guarantee such as fixed asset and or guarantor institution. Guarantor institution required by certain bank will make the customers become more prudent. Besides, guarantor institution highly determine the ability of sharia bank in mobilizing real sector through financing allocation to the rural area and small or medium enterprises. With mudharabah scheme, the institution will investigate the behavior of the partner so that the partner will be more reliable in managing the fund and partner will have more capability in the business.

Another effort that can be done is by deciding the maximum ratio of operational cost toward operation income. This is intended to make mudharib (customer) run the business efficiently. When the ratio reaches $100 \%$, it is proven that mudharib does not obtain operational profit. This situation certainly will not attract the capital owner to invest because there will be no profit to be shared. When the ratio reaches $80 \%$, there will be $20 \%$ of operational profit that can be shared with the capital owner. Moral hazard that may happen when doing financing process could be reduced with this mechanism.

Optimization of profit and loss sharing financing can also be supported by sustainability and information transparency about the business. This can be carried out through actual, detail, and factual database, which is adjusted to the form and climate of business run by the customer [9].

Improving portfolio of profit and loss sharing financing in sharia bank is not only the duty and responsibility of the bank but also the whole elements or stakeholders. Bank Indonesia as regulator should support this through the implementation of laws that protect and support the implementation of profit sharing principles. Sharia bank is also demanded to increase the realization of profit and loss sharing financing by reducing risks that may happen or risks that can be caused by moral hazard by improving the quality of human resources. In the other side, the customers as the related party should fully understand their roles to help managing funds properly and reliably.

Sharia bank as the bank that implements profit and loss sharing should increase the portion of its profit sharing. Profit and loss sharing financing (mudharabah and musyarakah) can mobilize real sector because this financing has productive feature that can be distributed for investment and working capital. Investment in real sector will certainly increase working opportunity and the reduce unemployment and in the same time improve the society" s income [5] 


\section{Conclusion}

Sharia bank as the bank that implements profit and loss sharing mechanism should have portfolio with dominant profit and loss sharing financing in its activities. However, this idealism has not happened in Indonesia. Recently, the financing in Indonesian sharia bank is still dominated by nonprofit sharing financing especially financing that uses akad murabahah. This situation is caused by following factors:

1) The bank plays the role as intermediary institution. In one side bank should provide profit and loss sharing for savers or depositors while in the other side bank should provide financing for society who needs financial assistance. The unpreparedness of the saving and deposit owners to cover loss consequently make the bank prefer to choose murabahah financing with certain payback rather than profit sharing which has potential of loss that may influence the decision of saving and deposit owners.

2) The regulation of Bank Indonesia has not fully support the implementation of profit sharing in which the customers are expected always to gain profit or good performance to be categorized as customers with smooth financing.

3) Analysis process of profit and loss sharing financing has higher level of difficulty because there is level of uncertainty of the business. This requires the human resource in finance and banking to be able to conduct financing process prudently. The limited competence of human resource has been one of the considerations of sharia bank to prioritize realization of financing with non profit sharing principle.

4) Asymmetric information can cause agency contractual that cause difficulty for bank to ensure that the business operation meets the initial agreement.

Thus, synergy from various stakeholders is needed to support sharia bank to run its role as profit sharing bank. In the end, this may contribute to mobilize real sector and improve the public quality of life. Sharia bank should improve its human resource competence to minimize the risks that may emerge in financing, such as by reducing asymmetric information.

The government as regulator should also support with accurate regulation to increase the profit and loss sharing financing. Government may also conduct continuous socialization about sharia bank especially profit and loss sharing financing to provide more knowledge about the concept for the society and to prevent damage in business such as side streaming. The customers should be educated to clearly understand about financing with profit loss sharing principles to increase the utilization of profit sharing financing (mudharabah and musyarakah).

\section{Acknowledgment}

I would like to express my very great appreciation to Diploma 3 of Economics Universitas Islam Indonesia who supported this research. My grateful thanks are also extended to Mr. Eko Daniel, Mr. Chawari Ata, Mr. Ahmad Rifky, Mr. Wawan, Mr. Bondan, Mr. Hari and Mrs. Lia for their advice on this research.

\section{References}

[1] Gema Insani. (2001). Islamic Banking: Bank Sharia dari Teori ke Praktek. Yogyakarta: Antonio Syafii.

[2] Bank Indonesia. Undang-Undang No 10 Tahun 1998 tentang Perbankan Syariah. Retrieved August 05, 2017, from, http://www.bi.go.id. 
[3] Bank Indonesia. Undang-Undang No 21 Tahun 2008 tentang Perbankan Syariah. Retrieved August 05, 2017, from, http://www.bi.go.id.

[4] Bank Indonesia. Statistik Perbankan Syariah. Retrieved August 05, 2017, from, http://www.bi.go.id.

[5] Beik Irfan Syauki. (2006). Bank Syariah dan Pengembangan Sektor Riil. Retrieved August 5, 2017, from www.pesantrenvirtual. com.

[6] Gramedia Pustaka. (2007). Bank dan Lembaga Keuangan Perbankan. Yogyakarta: Dhendawijaya Lukman.

[7] Darmawan. (2014). Bank Syariah Harus Perbesar Cadangan. Jakarta: Compliance News. No.44, Quarter II.

[8] Hadi, Chairul. (2011, March). Problematika Pembiayaan Mudharabah di Perbankan Sharia Indonesia. Jurnal Maslahah, 3(2). Retrieved July 14, 2017, from http://journal.uinjkt.ac.id/index.php/iqtishad/article/view/2521/ 1922.

[9] Imaduddin, Muhammad. (2005). Mudharabah dan Optimalisasi Sektor Riil. Retrieved September 7, 2017, from www.republika.co.id.

[10] Kompas Gramedia. (2014). Memahami Bisnis Bank Sharia. Modul Sertifikasi Tingkat I General Banking Syariah. Jakarta: Ikatan Bankir Indonesia.

[11] Israhadi, Evita. (2014, January). Investasi Bagi Hasil dalam Pembiayaan Akad Mudharabah Bank Sharia. Jurnal Lex Publica, 1(1). Retrieved August 5, 2017, from http://ejurnal.appthi.or.id/index.php/jurnalilmuhukumappthi/ article/view/14/14.

[12] Rajawali Pers. (2011). Bank Islam : Analisia Fiqh dan Kevangan. Jakarta:Karim Adiwarman.

[13] Khalil, Abdel-Fattah A.A., Colin Rickwood, and Victor Muride. (2000). "Agency Contractual in Profit Sharing Financing". Islamic Finance: Challenges and Opportunities in the twenty-first Century. Conference Papers, Fourth International Conference on Islamic Economic and Banking Loughborough University, UK, August 13-15.

[14] UII Press. (2005). Manajemen Bank Syari'ah. Edisi Revisi. Yogyakarta:Muhammad.

[15] Prasetyo. (2013). Identifikasi Faktor yang Mempengaruhi Rendahnya Pembiayaan Bagi Hasil Perbankan Sharia; Studi Kasus PT. BRI Sharia Kantor Cabang Malang. Jurnal IImiah, 1 (2). Retrieved August 5, 2017, from http://jimfeb.ub.ac.id/index.php/jimfeb/article/view/552.

[16] Prasetyanti. (2011, September). Pelaksanaan dan Sistem Bagi Hasil Pembiayaan al Mudharabah pada Bank Sharia. Jurnal keuangan dan Perbankan, 15(3). Retrieved July 14, 2017 from http://jurnal.unmer.ac.id/index.php/jkdp/article/.

[17] Warde, Ibrahim. (1999). The Revitalization of Islamic Profit-and-loss Sharing. Proceeding of the Harvard University Forum on Islamic Finance, October 1. Cambridge: Harvard Islamic Finance Information Program centre for Middle for Easter Studies.

[18] Aisyah Abul Rahman, Shifa Mohd Nor (2016, February). Challenges of profit-and-loss sharing financing in Malaysian Islamic banking. Malaysian Journal of Society and Space. Retrieved November 12 , 2017 , from http://www.ukm.my/geografia/images/upload/4x.geografia-si-feb 16-aisyah-edam.pdf.

[19] Gaffar Abdalla Ahmed. 2008. The implication of using profit and loss sharing modes of finance in the banking system, with a particular reference to equity participation (partnership) method in Sudan. Humanomics Journal. Volume 24:3, pp 182-206. 


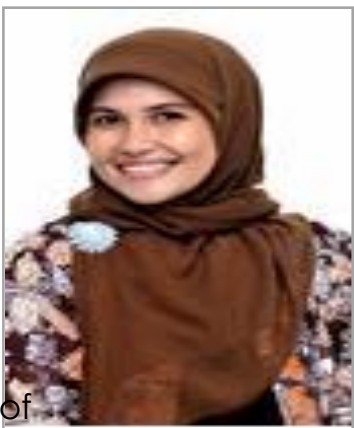

Born in Palembang October 10, 1981, Aidha Trisanty, S.E., M.M., CCS. Graduated from bachelor degree of Accounting at the Universitas Islam Indonesia (U.I.I.) in 2003. Afterwards, she gained her Master degree in Management from the same university in 2008. Prior to becoming a lecturer in Finance and Banking Diploma III of Economics U.I.I., the author worked and started her career in 2004 as a CUSTOMER SERVICE at Bank Syariah Mandiri of Surabaya Branch. In 2005 the author worked in Bank BTN Syariah until 2012 with the last position as CORPORATEMARKETING.

The author" s research interest mainly lies on sharia banking, both in the field service and in the operational of sharia banking. Some of her published works are: Service Excellence Competence; Added Value of Banking Vocational Students to Face Asean Economic Community (A.E.C.) which was published in the International Journal of GEOMATE in February 2017, and a research on Customer Satisfaction Analysis at Sharia Business Unit in Yogyakarta published in E-Journal of Management and Muamalah, Vol.6 No. 2 College Universiti Islam Antarbangsa, Malaysia in November 2016.

The author is currently registered as a member of the Indonesian Bankers Association (I.B.I.) since 2015 and is a competency assessor of the National Agency for Professional Certification (B.N.S.P.). Besides, she also has a technical competency certificate in the field of Customer Service and Funding Sales of B.N.S.P. 